15.Macijevsjkyj Ju. Chomu v nas nemaje politychnoji nauky. Krytyka, 2012. \# 6. S. 10-12.

16.Muljar V. I., Venghersjka V. O., Sukhachov S. Ja. Analiz navchaljnoji literatury z politychnoji nauky, vydanoji v Centraljnom i Zakhidnom reghionakh Ukrajiny. Politicheskaja nauka v Ukraine: stanovlenie i perspektivy. Simferopol', 2002. S. 97-143.

17.Nikolko M. V. Institucionalizacija politicheskoj nauki $\mathrm{v}$ Ukraine: analiz periodicheskih izdanij. Politicheskaja nauka v Ukraine: stanovlenie i perspektivy. Simferopol', 2002. S. 40-52.

18.Osin V., Zelenski A., Shuljak S. Vlast' i znanie na postsovetskom prostranstve: politicheskij rezhim, nauchnaja stepen', ideologija i kar'era v Ukraine i Moldove. Vil'njus, 2014. $376 \mathrm{~s}$.

19.Osin V. Nauka v novom mire: Tri sjuzheta genezisa regional'noj politologii v postsovetskoj Ukraine. Ab Imperio. Studies of New Imperial History and Nationalism in the Post-Soviet Space, 2015. №.4. S. 239-293.

20.Politicheskaja nauka v Ukraine: stanovlenie i perspektivy. Simferopol', 2002. 344 s.

21.Razdina E. V. Analiz uchebnoj literatury po politicheskoj nauke, ispol'zuemoj v vuzah vostochnogo regiona Ukrainy. Politicheskaja nauka v Ukraine: stanovlenie i perspektivy. Simferopol', 2002. S. 72-96.

22.Savel'eva I., Poletaev A. Klassicheskoe nasledie. Moskva: GU-VShJe, 2010. 336 s.

23.Starish O. Politychna nauka v Ukrajini: 20 rokiv nezalezhnosty. Krytyka, 2012. \#9-10. S. 27-29.

24.Filatov A. S. Analiz uchebnoj literatury po politicheskoj nauke, ispol'zuemoj v VUZah Ukrainy. Politicheskaja nauka v Ukraine: stanovlenie i perspektivy. Simferopol', 2002. S. 144-186.

25.Jetkind A. Vnutrennjaja kolonizacija. Imperskij opyt Rossii. Moskva: Novoe literaturnoe obozrenie, 2014. $448 \mathrm{~s}$.

DOI 10.31558/2617-0248.2021.6.7

УДК 323:81'272:32(001)

\title{
ІНСТИТУЦЙНІ ОСНОВИ МОДЕРНІЗАЦІЇ ПОЛІТИЧНИХ МЕРЕЖ МОДЕЛІ МОВНОЇ ПОЛІТИКИ
}

\author{
ORCID ID: https://orcid.org/0000-0002-5728-0686 \\ Савойська С. В., доктор наук в галузі політології, професор Міжрегіональної академії \\ управління персоналом
}

Досліджуються інституційні основи модернізації моделі мовної політики. Обґрунтовано, що інституційною основою модернізації політичних мереж моделі мовної політики є українська або ін. мова (у різні часи - це києворуська, церковнослов'янська, староукраїнська, руська та ін.) як державна інституція, яка у XV-му та XVI-му ст. використовувалася у церковних перекладах та у службі Божій. Мовна політика модернізації торкнулася церковної сфери саме тоді, коли українська церква стала незалежною, коли священики мали можливість проводити службу Божу та читати проповіді українською (церковнослов'янською) мовою.

Дається визначення поняття "модернізація», що розуміємо як: культурні і демократичні зміни; оновлення діяльності певної інституції чи галузі, яка несе значні рудименти минулого та підпорядкована його завданням; глибокі зміни в освітньому авторитарному світогляді; перегляд принципів функціонування освіти, ії реформування відповідно до нових вимог. Охарактеризовано діяльність тих інститутів, які незалежна Українська держава отримала у спадок від СРСР, однією із причин розпаду якого $€$ те, що ця наддержава намагалася побудувати безнаціональне одномовне суспільство, яке у нових демократичних умовах не може функціонувати конструктивно та повноцінно діяти. 3'ясовано, що ігнорування національних, зокрема мовних факторів, виявилося одним із чинників нежиттєздатності імперії, позаяк багатонаціональній державі потрібен плюралізм політичних та ідеологічних думок.

Акцентується увага на тому, що з відновленням незалежності нові демократичні інститути (інститут Президента, законодавчий інститут, яким $є$ в Україні Верховна Рада, виконавчий інститут - Кабінет Міністрів, а також мережа судових, комунікаційних, управлінських, освітніх та ін. інститутів) визначили тип побудови моделі мовної політики в Україні, яка є монокультурною, а також демократичний напрямок розвитку ї̈ мовної політики. Визначено, що індикатором політичних мереж моделі є українська мова як державна інституція, а також інші політичні інституції, які регулюють мовну політику, визначають їі вектор розвитку та розв'язують мовно-політичні проблеми. У цьому сенсі виявлено, що напруження виникає унаслідок конкуренції двох основних політичних інститутів та ̈і ідеологій - національно-демократичної та комуністичної, які провокують протистояння, приміром, у ділянках українського і російського націоналізмізмів. 3’ясовано, що модернізація

(C) Савойська С. В., 2021 
політичної мережи моделі мовної політики відбулася у добу правління Л. Кучми та інших проросійськи налаштованих політиків, які неухильно і цілеспрямовано вели українську спільноту до ії поляризації, розколу та мовно-політичної кризи. Враховуючи діяльність різних політичних інститутів, а також бачення розвитку держави та її моделі мовної політики, виявлено, що між «правими» (національнодемократичні політичні сили) та «лівими» (комуністи, соціалісти, соціал-демократи та ін.) політичними інститутами виникають непорозуміння, протистояння та мовно-політичні конфлікти, які відбуваються під час обговорення мовних законів, їх ратифікації та ухвалення. Доведено, що функціонування інститутів, які $€$ основою модернізації політичної мережи моделі мовної політики, залежить від ідеології, яка панує, політичної культури суб'єктів, політичної свідомості та політичної поведінки.

Ключові слова: модель мовної політики, політичні мережі, модернізація, інститути, незалежність, Україна.

\section{Savoyska S. V. Institutional fundamentals of modernization of political networks of the language policy model}

The institutional bases of modernization of the language policy model are investigated. It is substantiated that the institutional basis for the modernization of political networks of the language policy model is Ukrainian or other. language (at different times - it is Kiev, Church Slavonic, Old Ukrainian, Russian, etc.) as a state institution, which in the XV and XVI centuries. used in church translations and in the service of God. The language policy of modernization affected the church sphere precisely when the Ukrainian church became independent, when priests had the opportunity to conduct services and read sermons in Ukrainian (Church Slavonic).

The definition of "modernization" is given, which we understand as: cultural and democratic changes; renewal of the activity of a certain institution or branch, which carries significant vestiges of the past and is subordinated to its tasks; profound changes in the educational authoritarian worldview; revision of the principles of functioning of education, its reform in accordance with the new requirements. The activity of those institutions that the independent Ukrainian state inherited from the USSR is described, one of the reasons for its collapse is that this superpower tried to build a stateless monolingual society, which in the new democratic conditions cannot function constructively and fully. It turned out that ignoring national, in particular linguistic factors, was one of the factors of the viability of the empire, as a multinational state needs a pluralism of political and ideological views.

Emphasis is placed on the fact that with the restoration of independence, new democratic institutions (the President's Institute, the Legislative Institute, which is the Verkhovna Rada in Ukraine, the Executive Institute - the Cabinet of Ministers, and a network of judicial, communication, administrative, educational and other institutions) have defined the type of construction. model of language policy in Ukraine, which is monocultural, as well as - the democratic direction of development of its language policy. It is determined that the indicator of the political networks of the model is the Ukrainian language as a state institution, as well as other political institutions that regulate language policy, determine its vector of development and solve language and political problems.

In this sense, it is revealed that the tension arises due to the competition of two main political institutions and their ideologies - national-democratic and communist, which provoke confrontation, for example, in areas of Ukrainian and Russian nationalisms. It was found that the modernization of the political network of the language policy model took place during the rule of Kuchma and other pro-Russian politicians, who steadily and purposefully led the Ukrainian community to its polarization, division and language-political crisis. Given the activities of various political institutions, as well as the vision of the state and its model of language policy, it was found that between the "right" (national democratic political forces) and "left" (Communists, Socialists, Social Democrats, etc.) political institutions arise misunderstandings, confrontations and linguistic-political conflicts that occur during the discussion of language laws, their ratification and adoption.

It has been proven that the functioning of the institutions that are the basis for the modernization of the political network of the language policy model depends on the prevailing ideology, political culture of the subjects, political consciousness and political behavior.

Keywords: language policy model, political networks, modernization, institutions, independence, Ukraine

Постановка проблеми. Ефективна діяльність інститутів залежить від того, у якій державі вони діють та яка ідеологія панує. Приміром, у незалежній демократичній державі діяльність інститутів є вільнішою і прозорішою у порівнянні з тим, як вони функціонували в СРСР, тобто, в авторитарно-тоталітарному суспільстві. Модернізація політичної мережи моделі мовної політики відбувається ефективно унезалежній державі, 
де відновлюються та розбудовуються нові інститути влади. Модернізація мовно-освітньої політики на першому етапі (1991-1996 рр.) українського державотворення супроводжувалася: боротьбою між двома основними політичними інститутами, якими були національно-демократичні політичні сили, які відроджували свою діяльність, і комуністи, котрі намагалися утримати ту владу, що мали в СРСР; нестачею навчальних закладів, а також - вчителів і викладачів, які мали викладати предмети не лише українською мовою, а й мовами національних меншин; закриттям друкарень, які у 1990-х рр. належним чином не були забезпечені папером, фарбою, необхідним обладнанням та ін.; браком посібників, підручників, програм та інших навчальнометодичних матеріалів українською та ін. мовами нацменшин. На думку О.Новакової, модернізація - це частина трансформаційного процесу, коли система не тільки переходить до нового якісного стану, але й завдяки цьому підвищує свою ефективність [22, с. 9]. В Україні ці процеси розпочалися у добу перебудови та відродження незалежності, що супроводжувалося зіткненням старих (комуністичних) політичних сил, які намагалися зберегти статус кво, і нових, котрі продовжували формуватися у перші роки 1990-х, після президентських виборів 1994 р., «Помаранчевої революції», коли дві, ідеологічно протилежні політичні інституції не могли поділити перемогу під час виборів; у 2010 р. - після чергових президентських виборів, коли від проросійськи налаштованих політичних сил перемогу здобув В. Янукович; у 2014 р. - після «Революції гідності», коли на позачергових президентських виборах упевнену перемогу здобув П. Порошенко; у 2019 р. - на тлі ухвалення закону «Про забезпечення функціонування української мови як державної» та формування на цій основі моделі мовної політики упевнену перемогу здобув В. Зеленський, який у мовній політиці, намагається балансувати між проросійськи та проукраїнськи налаштованими політиками.

Аналіз останніх досліджень і публікацій. Окремі аспекти інституційних основ політичних мереж моделі мовної політики досліджували І. Бекешкіна [5], Б. Білик [6], Ю.Войтенко [9], О. Калиновська [13], I. Лопушинський [18], М. Пірен і В. Ребкало [24] та багато ін. Стратегічним завданням модернізації освіти на першому етапі державотворення $\epsilon$, на думку I. Лопушинського, вивчення української мови в усіх навчально-виховних закладах, поширення комунікації цією мовою та утвердження іiі у загальноосвітній, професійній та вищій школі [18, с. 19]. На думку вітчизняної соціологині І. Бекешкіної, у реформуванні освіти українська мова не завжди відіграє належну їй роль [5, с. 124], про що свідчить Стаття 7 закону «Про освіту», яку Венеціанська комісія визнала як таку, яка порушує в Україні права нацменшин. Ці та ін. мовно-політичні проблеми негативно відбилися на: забезпеченні освітніх закладів навчально-методичною літературою, українськомовними програмами, необхідними фахівцями та ін.; об'єднанні окремих гуманітарних предметів в один, заміні іспитів на заліки, зменшенні кількості лекційних та семінарських годин, що виділялися на вивчення деяких суспільних предметів, - усе це негативно впливає, як наголошують М. Пірен і В. Ребкало, на духовний розвиток особистості [24]. 3 іншого боку, ідея проросійськи налаштованих політиків у добу правління екс-Президента Януковича реформувати освітню галузь на місцях, зокрема на Півдні і Сході країни, також була, на думку Б. Білика, згубною для інших нацменшин та найчисельнішої корінної нації [6]. Боротьба за владу між зазначеними інституціями поглиблювала кризові явища, які полягали у тому, що на займаних посадах продовжували залишатися представники старих інститутів влади, які були зацікавлені у тому, щоб освіта у вузах українською мовою згорталася, фахівці скорочувалися, а престиж наукової та викладацької праці знижувався. Деякі україномовні друкарні узагалі вимушені були закриватися, бо не могли функціонувати на повну потужність із-за відсутності держзамовлень та необхідного обладнання, що раніше завозили з території інших республік, які входили до складу СРСР. У цій ситуації освітяни були змушені залишати викладацьку роботу та переходили в інші сфери діяльності. Тож політичну кризу в Україні, Ю. Войтенко пов'язує з мовно-політичними проблемами та міфами про небезпечного для проросійського українця «бандерівця», завдяки якому Росія створила ідеологічний розлом всередині українського суспільства [9, с. 296-297]. Це позначилося на гальмуванні поширення комунікацій українською мовою на Півдні і Сході країни, тобто у тих регіонах, які найбільше потребували українськомовних висококваліфікованих фахівців, щоб розробляти та втілювати у навчальний процес нові методичні матеріали, писати посібники і підручники українською мовою. Від цього постраждало також, як справедливо зазначає О. Калиновська, відродження національної системи освіти, яка базується на європейських принципах гуманізму і демократії [13, с. 196]. Наслідки від такої мовної політики обговорювали на колегіях Мінвузу України, на засіданнях Навчальнометодичних об'єднань та Науково-методичних комісій Мінвузу України, які були пов'язані з: виконанням закону «Про мови в Українській РСР», впровадження у життя якого було пов'язано 3 нестачею українськомовних фахівців, підручників, посібників та ін. навчально-методичної літератури; розширенням мережи шкіл, класів, груп у ВНЗ для отримання освіти українською та рідними мовами етнічних меншин; вивченням кримськотатарської, болгарської, гагаузької, новогрецької та ін. мов; підготовкою поступового переходу на навчання українською мовою у вищих та середніх навчальних закладах, що здійснювалося шляхом оновлення освіти у ділянці кадрової політики, яка була спрямована на підготовку необхідних спеціалістів у нових умовах модернізації освітньої галузі. Тобто, проблеми у сенсі функціонування інститутів держави у сфері мовної політики розпочалися з приходом до влади Л. Кучми і В. Януковича, за правління яких пріоритетом формування мовно-освітньої мережи моделі стала не українська, а російська мова. Щоб зберегти status quo для російської мови в Україні поціновувачі «лівої» ідеології та оточення Л. Кучми, які під час його правління створювали в Україні підгрунтя для поширення російської мови і культури, діючи 
всупереч національним інтересам, неодноразово звертали увагу на «насильницьку українізацію», тоді як насправді йшлося про певні обмеження російської мови, які були пов'язані лише з відродженням забороненої в Імперській Росії української мови і культури та - відновленням історичної справедливості, оскільки процес обмеження мовних прав українців у радянську добу тривав до кінця $1980-\mathrm{x}$ рр. У цьому сенсі ми маємо справу з двома політичними культурами (комуністична/радянська і національно-демократична/західна), які складаються в Україні з західної та східної культур.

Виклад основного матеріалу. Мовно-політична боротьба між старими (комуністи) i новими (національно-демократичні політичні сили) інститутами влади розгорілася під час аналізу та ухвалення статті 10 Конституції України, де позиції представників цих інститутів влади не співпадали. Політична позиція комуністів та представників національно-демократичних політичних сил з проблем відродження та використання української мови, а також мов національних меншин відбилася на Статті 10 Конституції України, яка, з одного боку, проголосила українську мову державною, з іншого, гарантувала вільний розвиток російської та ін. мов. Це положення закріплено також у Статті 53 Основного закону України, який гарантує право національним меншинам не на вивчення рідної мови, як це є практично в усіх європейських державах, а на «навчання рідною мовою у державних навчальних закладах» [16, с. 23]. Завдяки модернізації політичної мережи моделі мовної політики на першому етапі українського державотворення відбулися такі мовнополітичні процеси як: українізація сфер і галузей суспільно-політичного життя, яку було спрямовано на відродження та ефективне функціонування української мови, поширення іiї в усіх регіонах країни; забезпечення освітніх закладів українськомовною навчально-методичною літературою, відповідними фахівцями та ін.; мовно-політичні зміни в Українській церкві, ЗМI, у діловій сфері та ін. Тобто, на модернізацію освітньої мережи моделі мовної політики, на слушну думку І. Лопушинського, впливають соціальний, економічний, духовний стан суспільства, державні і політичні інститути, зокрема, політичні партії, громадські організації, українська і російська церкви, мовно-культурна єдність громадян, а також зовнішні чинники, зокрема Росія, Угорщина, Румунія, Свросоюз та ін. [18, с. 17]. Щоб усунути мовнополітичні та ін. проблеми, у 1995 році відбулися парламентські слухання, де було зазначено, що в Україні не створено жодного механізму для модернізації політичної та освітньої мереж моделі мовної політики. У зв'язку з цим, за словами І. Дзюби, «стали зникати ті умови, які робили цю модернізацію потрібною» [11, c. 470]. Для ефективного здійснення мовної політики та оновлення політичної мережи моделі на основі української мови, як однієї з головних державних інституцій, на другому етапі (1997-2004 рр.) за правління екс-Президента Л. Кучми почала формуватися ціла мережа нових інститутів, зокрема, у лютому 1997 року було відкрито Раду з питань мовної політики при Президенті України, яку було ліквідовано восени 2001 року. На важливості цієї інституції наголошує Ю. Чередник: «на іï засіданнях розглядалися, затверджувалися та подавалися на розгляд Президентові України доповіді про мовно-політичну ситуацію у державі та першочергові заходи щодо реалізації державної моделі мовної політики» [29, с. 10]. Влітку 1997 року було створено Департамент з мовної політики в структурі Державного комітету України у справах національностей та міграції, який - розформовано навесні 2000 р. 3 часом здійснення мовної політики було покладено на Державний комітет інформаційної політики телебачення і радіомовлення, позаяк ця інституція, як зазначає Ю. Чередник, «могла забезпечити виконання покладених на неї обов'язків лише у межах ії компетенції, які стосувалися засобів масової інформації та книговидавництва, яке занепадало. Водночас питання координації та контролю за проведенням державної мовної політики у роботі органів державної влади у сфері освіти були йому непідзвітні» [29, с. 11]. У подальшому мовну політику здійснювала така інституція як Управління з питань гуманітарної політики, яка діяла при Кабінеті Міністрів України, а також - сектор з мовної політики, який функціонував при Міністерстві культури і туризму України. Варто звернути увагу на те, що міністр юстиції С. Головатий за правління екс-Президента В. Ющенка наполягав на тому, щоб питання державної мовної політики було вилучене із компетенції міністерства культури та покладено на Міністерство юстиції України [10, с. 38]. Часта зміна цих інститутів негативно впливала на модернізацію мовно-освітньої, комунікаційної, культурної, ділової, духовної та ін. політики, якщо зважити, що протягом 1990-х років Міністерство освіти і науки у навчальний процес з кожним роком вводило нові гуманітарні курси, то у другій половині цього етапу та у його кінці кількість годин на їх вивчення скорочувалася [3, с. 105]. Окрім зазначеного, не сприяли відновленню колишньої кількості годин на вивчення гуманітарних курсів та зміні геополітичного курсу України, який у середині 1990-х рр. не підтримували національно-демократичні політичні сили, а у період 2014 - 2019 рр. - проросійськи налаштовані політики. Тобто, ті гуманітарні цінності, які В. Андрущенко назвав одними з пріоритетних складових моделі мовної політики держави, що були задекларовані політиками у перші роки проголошення незалежності, належним чином не виконувалися [4, с. 87]. Тож мовну політику у ділянці модернізації освітньої галузі можна назвати конструктивною та найбільш ефективною на першому етапі (1991-1996 рр.) оновлення політичної мережи моделі моделі мовної політики з таких причин: мовно-політична сфера упершій половині 1990-х рр. ще не була такою політизованою як у другій половині 1990-х рр., коли до влади прийшов Л. Кучма; політична та економічна кризи, розгубленість і нерозуміння як діяти змушували різних за ідеологією політиків сідати за стіл переговорів, йти на поступки, домовлятися та розв'язувати мовно-політичні проблеми. Завдяки інформатизації 
освіти, на слушну думку В. Андрущенка, ми маємо організувати навчання так, щоб високі інформаційні технології стали органічною потребою кожного викладача, аспіранта і студента [4, с. 565].

Водночас відносини між старими і новими інституціями ускладнилися на другому етапі (1997-2004рp.), що було пов'язано з ухваленням закону «Про ратифікацію Європейської хартії регіональних мов або мов меншин», де російська мова опинилася в одному ряду з тими мовами, які знаходяться на межі зникнення. Тобто, за правління Л. Кучми україномовний вектор моделі було загальмовано, а мовну політику спрямовано на формування в Україні мовно-освітньої та ін. мереж на російськомовній основі. Проблеми функціонування інститутів держави за правління екс-Президента Л. Кучми на другому етапі полягали у відсутності підтримки поширення української мови в освітній, інформаційній, діловій та ін. галузях і сферах суспільно-політичного життя на Півдні і Сході країни. У другій половині 1990-х pp. Л. Кучма намагався позбутися тих демократичних правил, які були вироблені національно-демократичними політичними інститутами у першій половині 1990-х рр. У зв'язку з цим мовна ситуація на цьому етапі здійснення мовної політики в Україні вважалася гіршою за ту, яка була на початку 1990-х рр., позаяк у 1999 році майже не видавали підручники українською мовою, не формували навчально-інформаційну базу, затягували розробку Державних стандартів вищої освіти та ін. Це відбувалося тому, на думку О. Тараненко, що мовна політика Л. Кучми та його інститути з середини 1990-х до кінця його правління орієнтувалися на Росію, російську мову і культуру, яка через проросійськи налаштованих політиків та їх інститути негативно впливала і продовжує впливати на усі процеси суспільно-політичного життя в Україні, зокрема, й під час президентських виборів 2004 року, які спровокували «Помаранчеву революцію». Якщо модель мовної політики «помаранчевої» влади можна охарактеризувати як популістську, метою якої, на думку А.Брацкі, було загравання з громадянами, утримання влади, здобуття їх прихильності через обіцянки [7, с. 247], то на етапі «Революції гідності» комунікативні дії проросійськи налаштованої влади варто розуміти як радикальні і сепаратистські. Свідченням такої мовної політики було ухвалення комуністами та ін. проросійськи налаштованими політиками закону «Про ратифікацію Свропейської хартії регіональних мов або мов меншин», який змінив ії вектор розвитку, порушивши Статтю 10 Конституції України. Цей закон набрав чинності 1 січня 2006 року та розколов українську спільноту за мовно-політичною ознакою. У цій мовно-політичній ситуації важко було знайти точки дотику між діями регіональної влади Півдня і Сходу країни та національно-демократичними політичними силами, які звинувачували один одного у порушенні прав людини. Така позиція проросійськи налаштованих політиків гальмувала навіть ті національно-політичні здобутки, які мали місце на початку 1990-х рр. Це було пов'язано з намаганням комуністів та ін. «лівих» політичних сил зберегти status quo для російської мови i культури, свою владу в Україні та вплив на здійснення мовної політики, щоб насправді ніяких змін не відбулося. Ця ідея набуває в Україні, на слушну думку В. Тарана, крайніх форм, наближаючись до ідеології російського великодержавного шовінізму з яскраво вираженою антиукраїнською спрямованістю [28, с. 35]. Водночас «праві» намагаються затвердити свою владу та розбудувати модель мовної політики на національній основі. Утім, у деградації всього українського зацікавлена Росія, яка, на думку І. Діяка, веде в Україні «боротьбу проти відродження української мови і культури, наполягаючи надати російській мові статусу другої, а насправді першої, державної» [12, с. 234]. Щоб досягти мети, проросійськи налаштовані політики масово завозили з Росії в Україну періодичні видання, підручники, посібники, художню, церковну та ін. літературу, яка упродовж багатьох років формувала в українців російську самосвідомість, спрямовану на підтримку російської мови і культури та блокування комунікацій українською мовою, що не сприяло, на думку О. Висоцького, формуванню національної свідомості, патріотичності та поширенню комунікацій українською мовою, особливо у зросійщених областях Сходу і Півдня країни та в АР Крим [8, с. 19].

На третьому етапі (2005-2009 рр.) функціонування офіційних інститутів за правління екс-Президента В. Ющенка, як і при Л. Кучмі, з'явилися механізми придушення свободи слова, де діяла заборона на висвітлення у ЗМІ потрібних для влади тем і фактів. У зв'язку з цим власники каналів переслідували та усували з ефіру небажаних журналістів, які послуговувалися українською мовою, прослуховували їх телефонні розмови, приховували від громадян правдиву інформацію, відмовляли у друкуванні та розповсюджуванні матеріалів незалежних 3MI, заарештовували тиражі газет, відключали трансляцію «5 каналу», ухвалювали замовні рішення у судах, які забороняли свободу слова і т. п. За висновками проросійські 3МI, що функціонують в Україні як приватні, або ті, які не відображають об'єктивну реальність, роблять велику шкоду для українського суспільства та держави у цілому. У цьому сенсі «інформаційна політична мережа, на слушну думку Т.Клинченко, стала ареною боротьби не лише різних політичних інтересів, а й мовно-культурних пріоритетів, які більшою мірою стосуються української і російської мов» [15, с. 216]. Проросійськи налаштовані політики та їх інститути, на думку І. Мацишиної, розкололи українську спільноту за ідеологічною, культурною, мовно-політичною та ін. ознаками, спровокувавши початок «Помаранчевої» революції і започаткувавши таким чином відторгнення Донбасу від України [20, с. 73]. «Помаранчева революція», а також дії проросійськи налаштованих політиків спровокували на Півдні і Сході України «парад мовних суверенітетів», місцеві інститути якого зберігали у мешканців цих регіонів проросійську свідомість та російську мову, яка була регіональною інституцією та основою формування в Україні російської політичної мережи моделі мовної політики. Громадський рух 2004 року, у порівнянні з «Революцією гідності», був більш поміркованим та менш радикальним, під час якого не пролилося жодної краплі крові та не була принижена 
гідність жодної з конфліктуючих сторон [25, с. 125]. Утім, наслідки від «Помаранчевої» революції, приміром, на Донеччині у добу правління «помаранчевої» влади були невтішні, якщо зважити на скорочення у навчальних закладах україномовних класів і груп та закриття навчальних закладів тому, що цей регіон донецька еліта вважає окремою і самодостатньою державою в Українській державі. Більше того, на думку I. Мацишиної, «Донецьк повинен сам керувати своїм регіоном та ухвалювати рішення на загальнодержавному рівні» [20, с. 70]. Тобто, на третьому етапі мовно-політичні комунікації спрямовувалися не на поширення української мови у російськомовних регіонах, що було так необхідно, а на підвищення статусу російської мови у якості регіональної. Про це свідчать дії місцевих інститутів влади Півдня і Сходу України, одні з яких намагалися надати російській мові статусу регіональної, інші блокували цю ідею на рівні місцевих судів. Такою діяльністю формальних і неформальних інститутів влади не були задоволені російські політики i науковці, зокрема С. Кичигін. На його думку, розвиток російської мови в Україні російськомовна українська еліта підтримує лише на словах, а тим часом кількість осіб в Україні, які вважають російську мову своєю рідною, скорочується. Щоб захистити іiі, необхідно більше видавати художніх журналів, на сторінках яких мають розміщуватися твори істинних талантів сучасності, без цього російська мова в Україні може перетворитися з великого російського слова у маргінальну мову [14, с. 4-5]. Таку думку С. Кичигіна та ін. російських політиків і так званих науковців спростовують окремі закордонні дослідники, зокрема Т. Дейк, Ю. Бестерс - Дільгер, які стверджують, що російській мові та російським комунікаціям в Україні ніщо не загрожує. Більше того, якщо на початку 90-х років XX ст. гуманітарна політика України спрямовувалася, на думку В. Андрущенка, на формування, розвиток та збереження загальноцивілізаційних цінностей [4, с. 88], то у добу «помаранчевої» влади, вона працювала проти модернізації освітньої, інформаційної, духовної та ін. мереж на україномовній основі. Основою мовно-освітньої мережи моделі мовної політики є: «Програма поліпшення вивчення української мови у загальноосвітніх навчальних закладах з навчанням мовами етнічних меншин на 2008-2011 роки», яка так і не була реалізована, позаяк була заблокована проросійськи налаштованими політиками, у розумінні яких українська мова є проблемною державною інституцією; закон «Про засади державної мовної політики», який розвернув вектор оновлення політичної мережи моделі мовної політики з прозахідного курсу на східний, позаяк цей закон з самого початку було спрямовано на загострення мовно-політичних конфліктів; закони «Про освіту» та «Про забезпечення функціонування української мови як державної», які були ухвалені національно-демократичними політичними силами Верховної Ради на четвертому етапі розбудови моделі мовної політики на україномовній основі.

3 приходом до влади В. Януковича розпочався четвертий етап (2010 - поч. 2020 рр.) здійснення мовної політики інститутами його влади, які мову i політику після «помаранчевого застою» повернули у російськомовне річище. Це не додало конструктиву у відносини, що існували між «правими» і «лівими» політичними інститутами, а породило нові проблеми, які стосувалися євроінтеграції українського народу або руху до союзу з Росією. Не сприяли єдності української спільноти та цілісності Української держави постійні протистояння між полярними політиками та їх інститутами, а також непорозуміння та мовно-політичні конфлікти, які були викликані масовим переведенням україномовних навчальних закладів на двомовний (російсько-український) або одномовний (російський) режим навчання та викладання. Така модель мовної політики формує, на думку Ю. Смольнікова [27, с. 19], грунт для запровадження українсько-російської двомовності на офіційному (державному) рівні, посилить російщення українського народу, знищить українську мову і культуру, поширить комунікації російською мовою та спровокує новий мовно-політичний конфлікт. Конфлікт мовно-політичний - це: зіткнення мовно-політичних та ін. інтересів суб’єктів політики, політичних інституцій, ідеологій та культур, що мають розбіжності у розумінні історії, мови, освіти, інформаційної політики та ін.; протистояння між владою, опозицією та громадянами, що виникають на грунті захисту та поширення однієї з мов, приміром, російської чи української. Утім, ніякого конструктиву між полярними політиками та їх інститутами, які є основою діяльності різних політичних мереж, не могло й бути, бо російсько-українські стосунки, на думку О. Пріцак, були нещирі і невідкриті, позаяк «у своїх взаєминах ці політики не говорили те, що думали, та робили те, що не хотіли» [26, с. 99]. Деструктивним прикладом у їх взаєминах є брак толерантності і культури щодо дражливих ідеологічних питань, приміром,- статусу російської мови, союзу України з Свропою чи Росією тощо. У такому разі питання ставиться не про інтеграцію чи об'єднання, а про повернення України до складу Російської Федерації» [12, с. 230]. Таке бажання В.Януковича та його оточення, на думку О. Майбороди і М. Панчука, використовується у політичних цілях [19, с. 205], що можна пояснити незацікавленістю української влади модернізувати інститути мовної політики на україномовній основі.

Проблеми у сфері модернізації моделі мовної політики України є тоді, коли має місце боротьба між: українським народом, з одного боку, і владними інститутами, з іншого, суб'єкти політики яких у суспільнополітичному житті «під тиском обставин користуються російською мовою, не зважаючи на те, що рідною мовою вважають українську» [23, с. 141]; російською та українською культурами, коли перша 3 них намагалася зберегти status quo, а друга- відновити права на використання і розвиток; двома режимами (тоталітарно-авторитарний i демократичний), тобто, між тим, який поступово відживає, i новим демократичним, який дає можливість вільно думати і діяти; ідеологіями - комуністичною або проросійською і національно-демократичною, які відображають європейський та азійський світи; політичними культурами 
(російською, румунською, угорською та українською), які, з одного боку, мають ознаки спадковості, з іншого, - набуті проблеми, що мають місце при вступі до вищих навчальних закладів, де дисципліни викладають українською мовою лише для того, щоб абітурієнти мали можливість скласти вступний іспит. Утім, таку модернізацію освітньої мережи моделі варто розуміти як не зовсім системну і послідовну, якщо зважити, що вона відбувається на фоні постійних зіткнень двох полярних політичних сил, їх інститутів, ідеологій та ідей, спираючись на підтримку тієї чи іншої частини української спільноти. Унаслідок такої моделі мовної політики в україномовних класах навчальних закладів освіти Севастополя до анексії Криму навчалося усього 755 учнів, що становило лише 1,9\% від загальної їх кількості. Водночас книговидання в АРК українською мовою було повністю відсутне, а серед 200 російськомовних видань- лише одна українськомовна тижнева газета Кримська світлиця [21, с. 270].

А власне інститутами модернізації політичної мережи моделі мовної політики у другій половині четвертого етапу (2014-2021 рр.) були міжнародні акти, підписані і ратифіковані Україною, укази ексПрезидента П. Порошенка, закони «Про вищу освіту», «Про освіту», «Про внесення змін до деяких законів України щодо мови аудіовізуальних (електронних) засобів масової інформації», «Про внесення змін до деяких законів України щодо частки музичних творів державною мовою у програмах телерадіоорганізацій», де зазначено, що аудіовізуальні (електронні) засоби масової інформації» і «телерадіоорганізації здійснюють мовлення державною мовою», «загальнотижневий обсяг мовлення державною мовою яких має становити не менше 75 відсотків». Водночас «мовлення телерадіоорганізацій місцевого значення має відповідати 60\%, а ті, які здійснюють мовлення мовами корінних народів, - не менше $30 \%$ у кожному проміжку часу між 07.00 i 18.00 та 18.00 і 22.00 год.». В іншому законі «Про внесення змін до деяких законів України щодо частки музичних творів державною мовою у програмах телерадіоорганізацій» у Статті 9, частинах 2 і 3 зазначено, що «телерадіоорганізації при здійсненні радіомовлення повинні забезпечувати частку пісень державною мовою в обсязі не менше 35 \% загального обсягу пісень, поширених у кожному проміжку часу між 07.00 і 14.00 та 15.00 і 22.00». Причім у цьому законі передбачено, що «протягом першого року пісень державною мовою має бути 25\%, протягом другого - 30\%, протягом третього - 35\%». Якщо «телерадіоорганізації поширюють музичні твори, серед яких частка пісень офіційними мовами Свропейського Союзу становить не менше $60 \%$, то водночас з цим вони повинні забезпечувати частку пісень державною мовою не менше $25 \%$ від загального обсягу пісень». Зокрема, у частині 5 Статті 9 зазначено, що «телерадіоорганізації при здійсненні радіомовлення забезпечують не менше $60 \%$ добового обсягу ведення передач, зокрема новинно-аналітичних блоків, розважальних передач (дикторами, ведучими радіопередач) державною мовою». Зокрема, у прикінцевих положеннях закону зазначено, що «мінімальна частка ведення передач державною мовою становить протягом першого року не менше 50\%, протягом другого - 55\%, протягом третього- $60 \% »$. У Статті 48, пункт 3 закону «Про вищу освіту» зазначено, що «заклади вищої освіти, створені на території України іноземними державами, а також заклади приватної форми власності мають право мову навчання обирати вільно». А що стосується державної мови, то вона тут лише «вивчається як навчальна дисципліна». Зокрема, закон «Про освіту», який Верховна Рада ухвалила 5 вересня 2017 року, то він також не забезпечує корінним народам, національним меншинам України, іноземним громадянам та особам без громадянства навчання українською мовою, про що свідчить Стаття 7, пунк 2 цього закону, а лише - «обов'язкове вивчення державної мови у закладах професійної (професійно-технічної) та вищої освіти». Водночас екс-Президент П. Порошенко запевнив, що єдиною державною мовою в Україні $\epsilon$ українська, бо так бажає понад $80 \%$ українців. Утім, закон «Про забезпечення функціонування української мови як державної» довелося українцям чекати аж до президентських виборів 2019 року. Цей закон разом з іншими дозволив ввести на радіо, телебаченні, в Інтернеті, друкованих засобах масової інформації більше української мови. У зв'язку 3 цим українська мова як єдина державна стала відігравати визначальну роль у формуванні мовної політики та iii моделі на основі консолідації української нації та іiі згуртуванні перед серйозними викликами сьогодення. «Українська нація/український народ, за визначенням В. Котигоренка,- це громадяни України всіх національностей, які утворюють спільноту, що продовжує багатовікову історію українського державотворення, дбає про забезпечення прав і свобод людини та гідних умов іiі життя, піклується про зміцнення громадянської злагоди, прагне розвивати та зміцнювати демократичну, соціальну та правову Українську державу» [17, с. 296]. У цілому, мовну політику в Україні окремі науковці і політики називають недолугою через ії непослідовність і маніпулятивність, якщо зважити, що закон «Про засади державної мовної політики» було скасовано аж через 6 років, а новий закон «Про забезпечення функціонування української мови як державної» було ухвалено під час другого туру президентських виборів 2019 року. За законом «Про забезпечення функціонування української мови як державної» основою державної мовної політики $\epsilon$ збереження незалежності, соборності, культури українського народу, цінностей держави, української мови як державної, яка є інструментом «об'єднання українського суспільства, засобом зміцнення єдності, територіальної цілісності України, незалежності та національної безпеки». Зазначений закон розробляв колектив фахівців Координаційної ради з питань застосування української мови в усіх сферах суспільнополітичного життя України, яку було створено при Міністерстві культури України 8 червня 2016 р. Ця інституція об’єднала представників наукової спільноти, органи виконавчої влади та громадянського суспільства, що варто розуміти як суспільство рівноправних і вільних громадян з високим рівнем економічної, 
соціальної, політичної, моральної культури, яке не залежить від держави, але є ії базисом та взаємодіє з нею, створюючи розвинені правові відносини заради загального блага. При Координаційній раді діяла робоча група з мовного законодавства, яка розробила зазначений проект закону разом з громадськими активістами i науковцями. У цьому сенсі майбутнє мовного законодавства та мовної політики в Україні, як наголошує Б.Ажнюк, «значною мірою залежить від громадської думки, активності недержавних організацій, а також від позиції експертного середовища та його здатності впливати на короткотермінові й далекосяжні цілі головних політичних сил» [1, с. 27, 28].

Згідно з даними Міністерства освіти, з 2014 по 2019 роки кількість російськомовних шкіл в Україні зменшилася втричі - з 621 до 194, з них приватних було 43. За цих обставин, на думку Б. Ажнюка, було б доцільно: створити в Україні державний орган, який би відповідав за розбудову моделі мовної політики на основі національних інтересів і цінностей, планував эї з урахуванням місцевих особливостей, звітував про досягнення і проблеми у мовній царині та був підзвітний громадськості, яку він повинен інформувати про мовну ситуацію у країні [2, с. 349-350]. Утім, така інституція як уповноважений із захисту державної мови, яку очолив Тарас Кремінь, уже існує. Однак у багатьох вітчизняних науковців виникає питання: мовний омбудсмен в Україні - це дієвий інструмент чи формальність? Тобто, мовне питання стоїть на порядку денному у нової влади, якщо зважити на передвиборчі заяви кандидата у президенти В. Зеленського та його однопартійців, зокрема М. Бужанського, які вимагають від Конституційного Суду розглянути положення закону «Про забезпечення функціонування української мови як державної», яке передбачає перехід учнів 5-11 класів російськомовних шкіл на українську мову навчання 31 вересня 2020 року. Зокрема, у Краматорському ліцеї імені Василя Стуса, де ще минулого року в шести класах дітей навчали російською мовою, перейшли цього року на українську. Не зважаючи на те, що по всій Україні на українську мову навчання у цьому році перейшло лише близько 200 російськомовних шкіл, не усі батьки, а особливо бабусідідусі, задоволені такою моделлю мовної політики. Виходячи з зазначеного, у липні цього року заступник голови фракції «Слуга народу» Олександр Корнієнко попросив внести до порядку денного роботи парламенту законопроєкт № 2362 депутата з його фракції М. Бужанського щодо навчання українською мовою у закладах освіти, який відхилив комітет Верховної Ради. Таким чином депутати поспішали загальмувати перехід навчання на українську мову, щоб не допустити цього до початку нового навчального року. У зв'язку з цим, це положення закону, на думку М.Бужанського та його однодумців, потрібно переглянути у Конституційному Суді як таке, яке порушує права російськомовних громадян. У цьому сенсі припускаємо, що конституційна криза в Україні частково пов'язана з мовною політикою, зокрема, - діючим мовним законом, який у фракції Слуга народу бажають переглянути, а Конституційний Суд не поспішає розглядати скарги депутатів.

Висновки. Отже, не зважаючи на певні труднощі, які у 1990-х рр. стосувалися книговидавничої, кадрової, інформаційно-комунікаційної, духовної та ін. сфер суспільно-політичного життя в сучасній Україні, модернізація освітньої мережи моделі мовної політики оновлювалася національно-демократичними інститутами у першій половині 1990-х рр. більш-менш успішно. Труднощі були пов'язані з економічними, фінансовими, мовно-політичними та ін. проблемами, а також-з символічною поведінкою проросійськи налаштованих політиків, яку формувала та якою керувала Росія. 3 приходом до влади Л. Кучми і В.Януковича, які зосереджували увагу на проблемі спільного українсько-російського інформаційного простору як сфери впливу на Україну, оновлення політологічного контексту моделі мовної політики було загальмовано. У цьому сенсі розпочалася боротьба за владу між двома інституціями, в основу якої вони поклали мовно-політичні проблеми. Унаслідок їх боротьби було змінено та загальмовано те українськомовне середовище, яке почало формуватися у кінці 1980 - на поч. 1990-х рр. Модернізація політологічного контексту моделі мовної політики на усіх етапах українського державотворення блокувалася комуністами та ін. «лівими» політичними силами. У зв’язку з ухваленням ряду законів в останні роки четвертого етапу (2010 рр. і до цього часу) мовнополітична ситуація стала поліпшуватися. Загалом, не зважаючи на перешкоди, які чиняться антиукраїнськи налаштованими інституціями, модернізація моделі мовної політики дала позитивні результати.

\section{Бібліографічний список:}

1. Ажнюк Б. Мовна політика: європейські критерії і Україна. Украӥнське мовознавство. Київський національний університет ім. Т. Шевченка. К., 2019. № 1 (49). С. 9 - 31.

2. Ажнюк Б. Шляхи і методи розширення сфери застосування української мови: концептуальні й практичні аспекти. Мовна ситуація в Україні: між конфліктом і консенсусом. К.: IПіЕНД імені I. Ф. Кураса НАН України, 2008. С. 343-367.

3. Андрусів В. Інституційний інтерес: виникнення та стратегічне значення / В. Андрусів. Стратегічні пріоритети. К., №1. 2006. С. 18-26.

4. Андрущенко В. Роздуми про освіту: Статті, нариси, інтерв’ю К.: Знання України. 2004. 737 с.

5. Бекешкіна I. Конфліктологічний підхід до сучасної ситуації в Україні / I. Бекешкіна. Київ: Абрис, 1994. $48 \mathrm{c}$.

6. Білик Б. Ідея введення другої державної мови в Україні- згубна для інших ії нацменшин, корінної нації. К.: Поліграфічний центр «Фоліант», 2006. Т. ІХ. С.154-160.

7. Брацкі А. Українське мовне питання чи питання української мови - соціо-психокультурний аспект. К.: Центр українознавства Київського національного у-ту ім. Т. Шевченка, 2012. Вип. 8. С. 86-89. 
8. Висоцький О. «Помаранчева» революція як зміна парадигм легітимаційної політики української влади. Гуманітарний журнал. Дніпропетровськ, 2004. № 3 (23). С. 95-101.

9. Войтенко Ю. Зіткнення цивілізацій і Україна: геополітичний вимір. Гілея: науковий вісник: збірник наукових праць / гол. ред. В. М. Вашкевич. К.: ПП «Видавництво «Гілея», 2014. Вип. 85 (6). С. 296-299.

10. Головатий С. Українська мова - інститут державності. Право Украӥни. 2016. № 3. С. 11-62.

11. Дзюба I. Нагнітання мороку: Від чорносотенців початку XX століття до українофобів початку століття XXI. К.: Вид. Дім «Києво-Могилянська академія», 2011. 503 с.

12. Діяк I. Українське відродження чи нова русифікація?: Наукове видання. К.: Гранослов, 2000. 304 с.

13. Калиновська О. Мовна ситуація в сфері освіти. Мовна політика та мовна ситуація в Україні: Аналіз і рекомендації / За ред. Юліане Бестерс - Дільгер. Вид. дім «Києво-Могилянська академія», 2008. С. 196-232.

14. Кичигин С. Война в четвертом измерении [Текст]: научно-художественная книга / С. А. Кичигин. 2-е изд., перераб. К. Молодь, 1989. 303 с.

15. Клинченко Т. Мовно-культурний розвиток в Україні: політичні відносини і культурні реалії. Національна інтеграція у полікультурному суспільстві: український досвід 1991-2000 років / Збірник. Відпов ред. І. Ф. Курас, О. М. Майборода. Київ: Інститут політичних і етнонаціональних досліджень НАН України, 2002. C. $215-238$.

16. Конституція України: Прийнята на п’ятій сесії Верховної Ради України 28 червня 1996 р. К.: Преса України, 1997. $80 \mathrm{c}$.

17. Котигоренко В. Ризики альтернативних версій мовної політики в Україні / Мовна ситуація в Україні: між конфліктом і консенсусом. К.: ІПіЕНД імені І.Ф.Кураса НАН України, 2008. С. 281-294.

18. Лопушинський I. Формування та реалізація державної мовної політики в галузі освіти України: Автореф. дис.... докт. політ. наук: 25. 00. 02 / Національна академія державного управління при Президентові України. К., 2008. 30 с.

19. Майборода О., Панчук М. Мовне та політико-ідеологічне протистояння в Україні: причини, чинники, прояви / Мовна ситуація в Україні: між конфліктом і консенсусом. К.: ІПіЕНД імені І. Ф. Кураса НАН України, 2008. С. 205-234.

20. Мацишина I. Регіональні еліти в контексті символізації (1994-2004 рр.). «Політичне життя». Вінниця, 2017. № 2. С. 68-74.

21. Нагорна Л. Політична мова і мовна політика: діапазон можливостей політичної лінгвістики. К.: Світогляд, 2005. 273 с.

22. Новакова О. Політична модернізація та розвиток демократичних процесів у сучасній Україні: Автореф. дис. ... докт. політ. наук: 23. 00. 02 / Національна академія наук України. Інститут політичних і етнонаціональних досліджень ім. І. Ф.Кураса. Київ, 2007. 33 с.

23. Науково - освітній потенціал нації: погляд у XXI ст.: У 3 кн. / Авт. кол.: В. Литвин (кер.), В. Андрущенко, С. Довгий та ін. К.: Навч. книга, 2003. Кн. 2: Освіта і наука. 636 с.

24. Пірен М., Ребкало В. Духовність особистості- основна цінність демократичного суспільства / М. Пірен, В. Ребкало. Вісник Національної академії державного управління при Президентові України. 2011. Вип. 2. С. 228-236.

25. Політико-ідеологічний процес в українському суспільстві в умовах модернізації: порівняльний аналіз. [Монографія] / За заг. ред. Ф. М. Рудича. К.: ІПіЕНД ім. І. Ф. Кураса НАН України, 2013. 448 с.

26. Пріцак О. Замість монологів і полемік - творчий діалог. Віче. 1994. №4 (25). С. 98-107.

27. Смольніков Ю. Проблема відродження української мови та історичної пам'яті в Україні (др. пол. 80-х - поч. 90-х рр. ХХ ст.). Теоретичний аналіз: Автореф. дис. ... канд. іст. наук: 07. 00. 01 / Нац. пед. ун-т ім. М. П. Драгоманова. Київ, 2005. 23 с.

28. Таран В. Концепція ідеології перехідного суспільства в контексті соціокультурного аналізу: Автореф. дис... д-ра філос. наук: 09. 00. 03 / Інститут філософії імені Г. С. Сковороди НАН України. К., 2001. $40 \mathrm{c}$.

29. Чередник Ю. Модернізація державної мовної політики в Україні: теоретико-методологічний аспект: Автореф. дис. ... канд. наук з державного управління: 25. 00. 01 / Дніпропетровський регіональний інститут державного управління Національної академії державного управління при Президентові України. Дніпропетровськ, 2011.23 с.

\section{References:}

1. Azhnyuk B. Language policy: European criteria and Ukraine. Ukrainian linguistics. Kyiv National University named after T. Shevchenko. K., 2019. № 1 (49). P. 9 - 31.

2. Azhniuk B. Ways and methods of expanding the scope of the Ukrainian language: conceptual and practical aspects. Language situation in Ukraine: between conflict and consensus. K.: IFiEND named after IF Kuras of the National Academy of Sciences of Ukraine, 2008. P. 343-367.

3. Andrusiv V. Institutional interest: emergence and strategic significance / V. Andrusiv. Strategic priorities. K., №1. 2006. P. 18-26. $737 \mathrm{p}$.

4. Andrushchenko V. Reflections on education: Articles, essays, interviews K.: Knowledge of Ukraine. 2004. 
5. Bekeshkina I. Conflictological approach to the current situation in Ukraine / I. Bekeshkina. Kyiv: Abris, 1994. 48 p.

6. Bilyk B. The idea of introducing a second state language in Ukraine is detrimental to other national minorities, the indigenous nation. K .: Polygraphic Center "Foliant", 2006. Vol. IX. P.154-160.

7. Bratsky A. Ukrainian language issue or the issue of the Ukrainian language - socio-psychocultural aspect. K.: Center for Ukrainian Studies of Kyiv National University named after T. Shevchenko, 2012. Vip. 8. P. 86-89.

8. Vysotskyy O. "Orange Revolution" as a paradigm shift in the legitimation policy of the Ukrainian government. Humanities magazine. Dnipropetrovsk, 2004. № 3 (23). P. 95-101.

9. Voitenko Y. Clash of civilizations and Ukraine: geopolitical dimension. Gileya: scientific bulletin: collection of scientific works / ch. ed. V.M. Vashkevych. K.: PE Publishing House "Gileya", 2014. Issue. 85 (6). P. $296-299$.

10. Golovaty S. Ukrainian language - the institution of statehood. Law of Ukraine. 2016. № 3. P. 11- 62.

11. Dziuba I. Injecting darkness: From the Black Hundreds of the early XX century to Ukrainophobes of the early XXI century. K.: Type. Kyiv-Mohyla Academy House, 2011. 503 p.

12. Diak I. Ukrainian revival or new Russification?: Scientific publication. K.: Granoslov, 2000. 304 p.

13. Kalinovska O. Language situation in the field of education. Language policy and language situation in Ukraine: Analysis and recommendations / Ed. Julianne Besters - Dilger. View. Kyiv-Mohyla Academy House, 2008. P. 196-232.

14. Kichygin S. War in the fourth dimension [Text]: scientific and artistic book / S.A. Kichygin. 2nd ed., Reworked. K. Youth, 1989. 303 p.

15. Klinchenko T. Linguistic and cultural development in Ukraine: political relations and cultural realities. National integration in a multicultural society: Ukrainian experience of 1991-2000 / Collection. Answer ed. IF Kuras, OM Mayboroda. Kyiv: Institute of Political and Ethnonational Studies of the National Academy of Sciences of Ukraine, 2002. P. 215-238.

16. Constitution of Ukraine: Adopted at the fifth session of the Verkhovna Rada of Ukraine on June 28, 1996. K .: Press of Ukraine, 1997. 80 p.

17. Kotygorenko V. Risks of alternative versions of language policy in Ukraine / Language situation in Ukraine: between conflict and consensus. K.: IPiEND named after IF Kuras of the National Academy of Sciences of Ukraine, 2008. P. 281-294.

18. Lopushynskyy I. Formation and implementation of state language policy in the field of education of Ukraine: Abstract. dis .... Dr. flight. Sciences: 25. 00. 02 / National Academy of Public Administration under the President of Ukraine. K., 2008. 30 p.

19. Mayboroda O., Panchuk M. Language and political and ideological confrontation in Ukraine: causes, factors, manifestations / Language situation in Ukraine: between conflict and consensus. K.: IFiEND named after IF Kuras of the National Academy of Sciences of Ukraine, 2008. P. 205-234.

20. Matsyshyna I. Regional elites in the context of symbolization (1994-2004). "Political life". Vinnytsia, 2017. № 2. P. 68-74.

21. Nagorna L. Political language and language policy: the range of possibilities of political linguistics. K.: Svitoglyad, 2005. 273 p.

22. Novakova O. Political modernization and development of democratic processes in modern Ukraine: Abstract. dis. ... Dr. flight. Sciences: 23. 00. 02 / National Academy of Sciences of Ukraine. Institute for Political and Ethnonational Studies. IF Kuras. Kyiv, 2007. 33 p.

23. Scientific - educational potential of the nation: a view in the XXI century.: In 3 books. / Author Col.: V. Lytvyn (supervisor), V. Andrushchenko, S. Dovhyy and others. K.: Навч. book, 2003. Book. 2: Education and science. $636 \mathrm{p}$.

24. Piren M., Rebkalo V. Spirituality of the individual - the main value of a democratic society / M. Piren, V. Rebkalo. Bulletin of the National Academy of Public Administration under the President of Ukraine. 2011. Vip. 2. P. 228-236.

25. Political and ideological process in Ukrainian society in the context of modernization: a comparative analysis. [Monographiya] / For the general. ed. FM Rudich. K.: IPiEND them. IF Kuras NAS of Ukraine, 2013. 448 p.

26. Pritsak O. Instead of monologues and polemics - creative dialogue. Chamber. 1994. №4 (25). P. 98-107.

27. Smolnikov Y. The problem of revival of the Ukrainian language and historical memory in Ukraine (second half of the 80 s - early 90 s of the twentieth century). Theoretical analysis: Abstract. dis. ... cand. ist. Sciences: 07. 00. 01 / Nat. ped. Univ. MP Dragomanova. Kyiv, 2005. 23 p.

28. Taran V. The concept of ideology of transitional society in the context of socio-cultural analysis: Abstract. dis ... Dr. Philos. Sciences: 09. 00. 03 / G.S. Skovoroda Institute of Philosophy of the National Academy of Sciences of Ukraine. K., 2001. 40 p.

29. Cherednyk Y. Modernization of state language policy in Ukraine: theoretical and methodological aspect: Abstract. dis. ... cand. Sciences in Public Administration: 25. 00. 01 / Dnipropetrovsk Regional Institute of Public Administration of the National Academy of Public Administration under the President of Ukraine. Dnepropetrovsk, 2011. 23 p. 